\author{
(online) $=$ ISSN $2285-3642$ \\ ISSN-L = $2285-3642$ \\ Journal of Economic Development, Environment and People \\ Volume 3, Issue 3, 2014 \\ URL: http://jedep.spiruharet.ro \\ e-mail: office jedep@spiruharet.ro
}

\title{
Evolution after 1990 of the Legal Framework with the Incidence on the Managerial Ethics of the Romanian Firms
}

\author{
Laurenția Georgeta Avram ${ }^{1}$ \\ ${ }^{1}$ Spiru Haret University, Faculty of Accounting and Finance, Câmpulung Muscel, Romania, \\ laura.avram@yahoo.com
}

\begin{abstract}
Firms with an ethical behaviour, which satisfy the conditions of morality, namely to respect applicable law articles, have certain characteristics: "balance between profit and ethics; ethical values underlying the daily behaviour of individual actions; penalty system which provides penalty and correction actions by unethical nature; set of values that involves treating others with respect and honesty as you want and to be treated; manufacture and marketing of the products so that you are be thankful if you use them; treating the environment as it would be your property".

In Romania, although the law has improved methodologically according to the European Directives, but problems arise in its implementation. The Commission report to the European Parliament and the Council on Progress in Romania under the Cooperation and Verification Mechanism \{SEC (2008) 2539\} show that Romania continues to face important difficulties in the functioning of its judiciary and fighting the corruption. In 2013, the political clienteles and corruption have worsened the Romanian state budget, representing, however, the greatest threat to the economic growth (MCV Report - 2013 - Brussels, 30.01.2013 COM (2013) 47 final). What are the solutions? There are the political stability and, not least, that constitutional.
\end{abstract}

Keywords: firm, ethics, law, commercial activity, illicit activities, competition, consumers

\section{JEL Codes: M21}

\section{Introduction}

In the period following of the 1989 Revolution, ethics was approached from the point of view of protecting the public against illicit activities, combating unfair competition, consumer protection, forms of corruption that occurs in the public or private sector etc.

\section{Romanian legal framework with the incidence on the managerial ethics}

Romanian legislation in fighting against the corrupt behaviour and encourage the ethical attitudes started with Law no. 12 of 8 August 1990 on the protection of the population against the illicit commercial activities. In order to create a competitive environment and a competitive internal market, principles 


\author{
(online) $=$ ISSN $2285-3642$ \\ ISSN-L = $2285-3642$ \\ Journal of Economic Development, Environment and People \\ Volume 3, Issue 3, 2014 \\ URL: http://jedep.spiruharet.ro \\ e-mail: office jedep@spiruharet.ro
}

provided by the Constitution of 1991, and given the economic climate developments in Romania in 2003, with the revision of the Constitution, it was felt the need to guarantee at the constitutional level of the economic freedom principle which, together with the free initiative, is the foundation of the market economy. This fundamental right is governed by Article 45 of the Constitution which, in conjunction with Article 135 of the Basic Law stipulates that Romania's economy is the market economy based on the free enterprise and competition. Also, the state is obliged to ensure the free trade, protection of fair competition and the favourable framework for valuing of all factors of production.

Anti-competitive practices are the dishonest ways used by some economic agents to attract the competitors' customers. The Law no. 11/1991 on combating the unfair competition defines the principles for applying and regulating the anti-competitive practices. In terms we are concerned, we have some reservations about the need to criminalize provided by Article 5 thereof (Article 5, paragraph $1 \mathrm{a}-\mathrm{b}$ : using a business name, an emblem, special designations or packaging likely to cause confusion with the legitimate ones used by another trader, production in any way, import, export, storing, selling or offering for sale of some goods wearing false inscriptions on the invention patents, origin and characteristics of the goods and the name of the manufacturer or dealer in order to mislead other traders and consumers.)

In this regard, a first argument would address the idea of legislative coherence needed to any legal systems to reinforce the concept of justice. Article 5 letter b) of the Law is situated in a qualifications competition with a number of other criminality provided in the special legislation and in the Criminal Code in force. Noting for these offenses, the criminal action shall be initiated upon the prior complaint and the withdrawal of the complaint or reconciliation of the parties removes the criminal responsibility, whereas GEO 190/28.12.2005 was not removed the prior complaint procedure. However, we do not dismiss the importance of providing the adequate protection for trademarks. Buyers can not always investigate thoroughly the quality of a product. Therefore, the major investments in building a brand - around a brand solve, to some extent, this issue. However, those mentioned do not justify criminalization provided by Article 5 letter b), since a similar protection can be provided by Law no. 84/1998 on the trademarks and geographical indications.

A second possible argument could be based on the applicability of the principle of minimal intervention in the criminal law. Thus the criminalization mentioned is the general framework for counterfeiting or pirating the goods. It remains therefore questionable to what extent certain undesirable behaviours produce damaging of the social values protected by the rule of criminality, so that to fully justify the intervention of the criminal law. The discussion requires reporting, firstly, on the social values damaged by the commission of the offense, but also on the existence of other non-criminal mechanisms would be liable to effectively combat this anticompetitive phenomenon.

Analyzing the liable social values to be damaged by the commission of the offense, we can identify the competition observance (fair) and the consumer protection. These arise both in the content of Article 1 of the law subject to discussion and typicality of the crime itself. Thus, we wonder to what extent the competition observance - the social value - could not receive the adequate protection only through the intervention of the Competition Council. This is because, under the principle of the minimal intervention, not any social value recognized by the legal system justifies the protection under the criminal law. 


\author{
(online) $=$ ISSN $2285-3642$ \\ ISSN-L = $2285-3642$ \\ Journal of Economic Development, Environment and People \\ Volume 3, Issue 3, 2014 \\ URL: http://jedep.spiruharet.ro \\ e-mail: office jedep@spiruharet.ro
}

Moreover, we have reservations to consider that misleading the consumers could justify in abstract, the intervention of the criminal law. In case of counterfeiting the drugs, or other goods or services that may endanger the life or health of the consumers, such interference by criminal law could be justified. However, since the Article 5 letter b) of the Law has applied to all acts of circulation, the simply misleading the consumer is definitely insufficient to prove compliance with requirements derived from ultimate ratio character of the criminal law.

In the Romanian legislation the unfair terms have special regulation by Law no. 193/2000 on unfair terms in the contracts concluded between traders and consumers, and by Law no. 296/2004 on the Consumer Code, Ordinance no. 21 of 21 August 1992 on consumer protection with subsequently amended, Law no. 240 of 7 June 2004 on the producers' liability for damages caused by the defective products. Also, some provisions of the Civil Code have an impact in the field of the unfair terms and, as well as Article 5 , Article 966-968, Article 970, Article 977-985, Article 1069, Article 1070, Article 1072, Article 1086 and Article 1087. Rules applicable to the unfair terms are recognized and in the Article 1541 of Law no. 287/2009 on the Civil Code.

In the community law, several regulations have been adopted in this area, namely: Resolution of 14 April 1975 of the European Communities Council, which was approved preliminary program of consumer protection; European Council Recommendation of 16 November 1976 on the unfair terms in the consumer contracts, EU Directive no. 93/13/EEC on the unfair terms concluded with consumers, implemented in our positive law by Law no. 193/2000 on the unfair terms in contracts concluded between traders and consumers. It is estimated that a trader meets the requirement of good faith when acting fairly and equitably against the other party whose legitimate interests must be taken into account.

According to the mentioned Directive " for appreciation of the good faith must be given a special attention to the force of the bargaining positions of the parties, the fact of whether the consumer was encouraged to give their consent to the clause in question and whether the goods or services were sold or supplied to express request of the consumer", "provided in good faith may be satisfied by the seller or supplier when it actions fairly and equitably with the other party whose legitimate interests must be taken into account". We appreciate the good faith reporting requirements in the definition of the unfair terms is not necessary because, first, the contractor seeks an unreasonable advantage over the other Contracting Party shall be deemed to be in the bad faith. On the other hand, good faith is evoked by Article 970 Civil Code. Reference to good faith in the definition of the unfair terms is unnecessary, since Article 970 Civil Code is inevitably implemented. The legislator sanctioned such clauses, considering that their stipulation in a contract, or more specifically their imposition by one party to the other party (in a state of inferiority or need etc.), gives expression to the contractual abuse. Taking into account that the unfair terms is not restricted only to the contractual relations between traders and consumers, but also covers the contractual relationships in general, and the law provides specific penalties only in case of the unfair terms in the contracts made between the traders and consumers, the court plays an important role to invalidate the unfair contract terms stipulated in other types of contracts, applying the rules of the common law.

On 21 January 2003, the Romanian Parliament adopted the Law no. 52/2003, which, as it is shown in the explanatory memorandum that accompanied it, was intended to achieve, along with Law no. 544/2001 on free access to information of public interest recently adopted at that time, a substantial reform of the 


\author{
(online) = ISSN $2285-3642$ \\ ISSN-L = $2285-3642$ \\ Journal of Economic Development, Environment and People \\ Volume 3, Issue 3, 2014 \\ URL: $\underline{\text { http://jedep.spiruharet.ro }}$ \\ e-mail: office jedep@spiruharet.ro
}

public administration. In this way, citizens, and members of the business community will be able to participate in decision-making in the public administration in Romania.

"Whatever the government and political colour have been in Romania, the enhancing transparency and the public administration reform has remained a hot topic on the political agenda. It is believed that transparency is one of the central pillars of a European style government, the standards of which Romania had to fulfil to join the European Union. Hence the continuous obsession to search patterns and reforms that give content to administrative transparency principle. In the Romanian doctrine, the transparency is associated with the idea of opening the administration, a phenomenon that allows absorption of opinions and ideas coming from outside". This is reflected in the advertising of the administration actions and participation in decision making of the persons whose interests are at stake, with the direct access it is realized the proximity between citizens and the public administration. "Transparency is designed to make administration less opaque to clear the fog that surrounds it, to break the wall of silence; it involves removing the secrecy rule of the administration activity, which is the last redoubt of the bureaucratic construction".

In the year 2012, the reality proves that there is still a large gap between the administration and the administered. Either we talk about under technical or logistical equipment, the slowness, the carelessness of officials and the queues at the counter, the lack of courtesy and contemptuous behaviour of public servants; they are real facets of the public administration in Romania that can combat any opinions savanteuphoric or politicking on the reforming of the administrative system. Just because there are real samples about it mustn't practice the administration in a democratic state, it is necessary to be found ways to improve the services provided by the administration, to increase efficiency of the public authorities activities, so that the people no longer have suffered because the deficiencies of the system.

The limits of transparency result from the actual content of the reforms initiated by the authorities in this regard. Information policy is only in an early stage in the achievement of the administrative transparency. The main objective remains to eliminate the ignorance or malevolence in the activity of the public administration, the practice demonstrating once again that the proclaimed desire to make from the public administration a house of glass remains illusory. It is important that, once registered on deepening the transparency policies, the measures taken from the top of the administrative pyramid to its base, to respect such an orientation. This means that all institutions falling under the Law no. 52/2003 to be obliged under the threat of the severe penalties provided by law to respect the established standards.

Ethical considerations are important for the public activity in the different ways. What is happening in the public management not only depends on the choices of those involved in this activity, and their choices are influenced naturally by the ethics they proved. Another influential factor is the role of the state.

Ineffectiveness and inefficiency of the communication is a major nowadays issue. The communication inability does not show as a unique social phenomenon but in combination with other phenomena such as emphasizing psychological distance between people based on the national criteria, racial and ethnic, spiritual isolation of the people through their integration into the large industrial and urban complexes, dehumanization of the interpersonal relationships as a result of the "affective vitamin deficiency" of the totalitarianism or of the money force domination etc. In general, our ability to achieve the spontaneous and creative human contact is paralyzed by the frantic pace of the modern life and daily stress. On the other 


\author{
(online) = ISSN $2285-3642$ \\ ISSN-L = 2285-3642 \\ Journal of Economic Development, Environment and People \\ Volume 3, Issue 3, 2014 \\ URL: $\underline{\text { http://jedep.spiruharet.ro }}$ \\ e-mail: office jedep@spiruharet.ro
}

hand, the current business environment is characterized by explosion of information technology, globalization of economies, the acute economic crisis in some areas, increasing the number of the pressure groups in the consumer-syndicates-government relations, increasing the technological competition, deepening the specialization and diversification.

Fight against the opacity of public administration is conducted in an extremely slow pace, because this situation can be both the institutional and the legal framework with the incidence in the field. It is both the officials' fault that treat superficially or slowness the requests received and the institution that does not organize a more effective communication and interaction spaces for citizens - cyberspace, websites, specialized offices, so that to operate according to the standards prescribed by law. The legal framework also bears a part of the blame through the lack of explicit penalties for the authorities and the officials and of some provisions to responsible both parties not to send someone to court (action involves some cost and time) to solve problems that may arise due to the lack of transparency of the authorities.

Law no. 149 of 5 July 2011 approving Government Emergency Ordinance no. 75/2010 on the amending and supplementing of the Competition Law no. 21/1996. The new regulations create the premises for institutional strengthening of the Competition Council and making efficient its intervention when there are signs from the market about the possible anticompetitive practices. The Competition Council shall be constituted as a new formula designed to increase the level of professionalism and independence of the management of the institution. However, the national procedures are adapted to the EC provisions in the competition field. More specifically, there are accepted the interim measures and commitments from the investigated companies, the penalty may be suspended only after paying a bail, increasing the share of the economic analysis to identify the anticompetitive practices. However, in order to a procedural optimize were simplified the steps that must be followed in terms of the economic merger.

Government Decision no. 1.553/2004 of 23 September 2004 on ways to stop the illicit practices in the protection of the collective interests of consumers aims to cessation of the illegal practices in order to increase the protection of the collective interests of the consumers and improve the legal relationship between consumers and economic operators. In this context, when the collective interests of the consumers in a Member State of the European Union are harmed by illegal acts committed on the territory of Romania or their authors are domiciled in Romania, the authorized organizations in that state have the opportunity to seize the competent authorities in Romania in taking and handling of the complaints.

World economic development has generated progress and expansion of methods and techniques for obtaining "black" capital, which constantly attempted and continues to attempt to be given by its owners the legality affiliation. Black Capital represents the amount of money or other property values acquired by one or more persons after intentionally committing or participation in the commission of an offense condemned by the law, having an aim and result to obtain the illicit profits.

In this context, amid of the transition to a market economy, in Romania was found increasing the professionalism and inventiveness of the interested people in the functioning of the underground economy in which the statutory financial circuits are bypassed, the obvious purpose being to obtain sums from illegalities, and, not least, recycling goods and the assets acquired fraudulently.

In the Romanian legislation, the term of money laundering was consecrated by the provisions of Law no. $21 / 1999$, normative act that was part included, at that time, in the large share of harmonization of the 


\author{
(online) $=$ ISSN $2285-3642$ \\ ISSN-L = 2285-3642 \\ Journal of Economic Development, Environment and People \\ Volume 3, Issue 3, 2014 \\ URL: $\underline{\text { http://jedep.spiruharet.ro }}$ \\ e-mail: office jedep@spiruharet.ro
}

national legislation with EU legislation. Law no. 21/1999 was repealed on December 7, 2002, when the Romanian Parliament adopted the Law no. 656/2002 on preventing and sanctioning the money laundering and for the establishment of measures to prevent and combat financing of the terrorist acts.

National Office for Prevention and Control of Money Laundering functions as a specialized institution with legal personality under the Government, and has, according to Article 19 paragraph (2) of Law no. $656 / 2002$, the object of activity "preventing and combating money laundering and financing of the terrorist acts, purpose in receiving, analyzing, processing information and notify, under Article 6 paragraph (1), the Prosecutor's Office attached to the High Court of Cassation and Justice, and in case it is found the financing of the terrorism acts, it shall immediately notify the Romanian Intelligence Service on the suspected operations of financing of the terrorist acts".

Escapist behaviour is intentional premeditated, but also involves the legal issues. Thus, because the fiscal pressure many economic agents have resorted to use for their business of the micro enterprise status to remuneration the executive level, by resorting the legal process to avoid the salaries taxation.

I share the view of the post-revolutionary Romanian legislators who have created these gaps in the legislative framework for two reasons: offering the capitalization of some people for completion the privatization process and satisfaction of the political customer.

The illegal or actual tax evasion is the taxpayer action of flagrant violation of the relevant laws. It is so called the tax fraud. This fraud is realised by not submitting or filing the incorrect tax returns. It is known that our tax system is the declarative one.

Forms of the tax fraud under Law no. $241 / 2005$ to combat the tax evasion are the unjustified refusal to submit to the control, prevent the competent authorities of the audit, not paying the withholding taxes, highlighting the false accounting expenses, the fictitious declaring of the main or secondary headquarters or not their declaring and so on, all of which have as result diminishing the tax base.

In this area, the most common tax evasion is hiding the taxable source. The most critical and exhibited field of this phenomenon are those of the excisable products, especially the mineral oils, alcohol and tobacco.

The concept of corruption is defined by several international organizations, UNO, EU and NGOs, notably Transparency International, which have the task or run the programs to prevent and combat the corruption. Thus, as defined by Transparency International, the corruption means "misuse of entrusted power, either in the public or the private sector in order to meet personal or group interests". According to the National Anticorruption Strategy 2005-2007, corruption is "systematic deviation from the principles of impartiality and fairness that must underlie the functioning of the public administration and assume that the public assets to be distributed universally, fairly and equally and replacing them with practices that allocation to certain individuals or groups of a disproportionate part of the public goods relative to their contribution".

In all official documents or of the NGOs, with some differences and noticeable nuances, corruption is presented as a major negative point as a "disease" of the Romanian society. Corruption undermines the effectiveness and legitimacy of state institutions and limited the economic development of Romania. In addition the perception of corruption shows the low level of the public trust in the state institutions. 


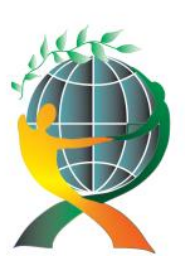

\author{
(online) $=$ ISSN $2285-3642$ \\ ISSN-L = 2285 - 3642 \\ Journal of Economic Development, Environment and People \\ Volume 3, Issue 3, 2014 \\ URL: http://jedep.spiruharet.ro \\ e-mail: office jedep@spiruharet.ro
}

An example is given by the Report on evolution of the accompanying measures in Romania after accession in which the European Commission considers the legal framework for combating the corruption as a quite well developed but its application remains weak. There is still a clear weakness in transforming of these intentions into results and the realised progress in the short time that has elapsed since the establishment of the mechanism for cooperation and verification are still insufficient. The deeply rooted problems, especially the corruption, require the irreversible establishment and effective functioning of some sustainable structures at the criminal investigation and the law enforcement level, capable of sending strong dissuasive signals.

Law no. 78/2000 on preventing, discovering and sanctioning corruption, amended and updated, is a means of control and punishment of all the acts or omissions that lead undoubtedly to the offence of the corruption act.

By Decision no. 609/ June 4, 2008 approved the National Anticorruption Strategy on the vulnerable sectors and local public administration over the period 2008-2010. Strategy proposed measures which complement the Public Administration Reform Strategy and Objective no. 1 Increasing the transparency and integrity in the public administration from the National Anticorruption Strategy 2005 - 2007. However, in the strategy there are considered the conclusions of some institutional assessments, governmental and nongovernmental, realised in Romania, but also from the external sources.

Law no. 137/2005 on environmental protection and Emergency Ordinance no. 195/2005 considering the environmental protection as a goal of public interest and to ensure the sustainable development of the society, ensuring the appropriate sanctions for failure. The legal liability has a special character for the area to which we refer. Liability for damages appears seems to be based on breach of the legal obligation for all individuals and legal persons to protect the environment. That does not mean, however, an exception to the general principle that anyone who causes damage should repair it. That will be the specific of that liability are conditions of incurring of the liability and how to repair the damage from the point of view of the author and establish the victim entitled to repair.

The principle of the objective liability is, moreover, only able to implement the polluter pays pollution (PPP) principle, the liability is engaged for the risk presented by the activity which it is conducted.

As for the damage reparation, in the Environmental Framework Law it is mentioned that the author incurring the cost of the damage repairing and removes its traces, restoring the previous conditions of the prejudice occurrence. Of course, this statement takes into account the individuals or legal persons whose liability has been established, aiming to fully repair of the damage, including bringing to the previous state of the environment to which it has been achieving, so, including the ecological restoration, if it is possible.

European Commission Decision no. 2006/928/EC for establishing a mechanism for cooperation and verification (MCV) of the realised progress in Romania to achieve certain specific benchmarks in the areas of the judicial system reform and fighting against corruption - Conditioning no. 2 for Romania, led to setting up in the Romanian legal system of a legal institutions such as the National Integrity Agency (ANI).

In this context, the starting point in the development of the Agency is consisted by the mentioned Decision, namely Law no. 144/2007 regarding the setting up, organization and functioning of the National Integrity Agency (ANI). Through this law, according to the commitments, the Agency is confined to a specific area of action, namely to ensure the exercise of the public functions and dignities in terms of 


\author{
(online) = ISSN $2285-3642$ \\ ISSN-L = 2285-3642 \\ Journal of Economic Development, Environment and People \\ Volume 3, Issue 3, 2014 \\ URL: $\underline{\text { http://jedep.spiruharet.ro }}$ \\ e-mail: office jedep@spiruharet.ro
}

impartiality, integrity and transparency. The scope of the Agency is represented by the organization in a unitary and institutionalized manner of the control activity of the property acquired during the exercise of mandates or performing the functions or public dignities and the verification activities of the situations where conflicts of interest and incompatibilities arise. Specifically, the control of the wealth and checking the conflicts of interest and incompatibilities are performed by the integrity inspectors of the agency.

Law no. 176 of 1 September 2010 on the integrity in performing the functions and public dignities, for amending and supplementing the Law no. 144/2007 and for amending and supplementing other acts, actually led to the transformation of Law no. 144/2007 in a simple legislative act for the organization and functioning of the institution.

Legislation in Romania on the protection of the population against the illicit activities, combating the unfair competition, consumer protection, forms of corruption that occurs in the public or private sector, was in a permanent change, which has improved the legal framework affecting the ethical management of the firms.

Positive aspects, if you can call them, result from the current reality of improving the legal framework affecting the ethical management of the firms in the year 2013. So, if the laws of Romania in combating the corruption behaviour and encouraging the ethical attitudes started with Law no. 12 of 8 August 1990 on the protection of the population against of some illicit commercial activities, that directly led to creation of a competitive environment and a competitive internal market. Constitution of Romania guarantees as a principle value the economic freedom that together with the free enterprise is the foundation of the market economy. In this context, signing by Romania of the various documents, pacts, treaties regarding the copyright and related rights, industrial property, led to the adoption in 1998 of Law no. 84 on trademarks and geographical indications.

Since joining the European Union, the legislative activity was improved by aligning with the acquis communitarian. Although Romania is trying to fulfil the objectives set by the treaties, not infrequently, it is condemned for mismanagement and law enforcement. An eloquent example is the one in which the Court of Justice of the European Union regarding the Directive on copyright, mentions in a report that it has not been correctly transposed into the Romanian legislation.

Regarding the anti-competitive practices, they have shown and will continue to produce its devastating effects. A first step was the adoption of Law no. 11/1991 on combating the unfair competition. Of course this area has improved in terms of legislation, but as counteracting of the phenomenon, the appropriate authorities declared they were quite often helpless. Only in 2009 the parliamentarians voted a law to prevent the anti-competitive practices of the supermarkets.

Combating the tax evasion is one of the most difficult phenomena to combat. Law no. 241/2005 to combat the tax evasion provides means of repression of hiding the taxable source. The most critical and exposed areas are those of excisable products, especially the mineral oils, alcohol and tobacco. At the European and the world level have searched different sustainable solutions to combat the tax evasion (Action Plan to strengthen the fight against the fraud and the tax evasion - Brussels, XXX COM (2012) $722 / 2$ ), solutions that, unfortunately, are far behind the methods used by offenders. At the European level, about a thousand billion Euros are lost each year through the evasion and the tax fraud. 


\author{
(online) = ISSN $2285-3642$ \\ ISSN-L = $2285-3642$ \\ Journal of Economic Development, Environment and People \\ Volume 3, Issue 3, 2014 \\ URL: $\underline{\text { http://jedep.spiruharet.ro }}$ \\ e-mail: office jedep@spiruharet.ro
}

\title{
3. Conclusion
}

In conclusion, we can say that in an Europe terror by incapacity to pay salaries and pensions, to preserve the jobs, threatened by withdrawal of the powerful economical states of European Union, Romania has the capacity to coordinate an appropriate legal framework where the legislation commits the long-term performance, to combat the illicit activities, unfair competition, forms of corruption that occurs in the public or private sector; consumer protection, etc.

\section{References}

[1] Bălan, E., Drept administrativ şi procedură administrativă, Universitara Publishing House, Bucharest, 2002, p. 148

[2] Chevallier, J., La transformation de la relation administrative: mythe ou realité? apud. M. Rasera, La démocratie locale, L.C.D.J., Paris, 2002, p. 97

[3] George, Gîrleşteanu, Evoluţii legislative şi jurisprudenţiale române în materia Legii nr. 144/2007 privind Agenţia Naţională de Integritate, in Journal of Legal Sciences no. 2/2010, p. 7.

[4] Goldstone, D., J., The Criminalization of Trademark Counterfeiting, in: Connecticut Law Review, vol. 31, no. 1, 1998, p. 4.

[5] Healy, P., and Serafeim, G., Causes and Consequences of Firms' Anticorruption Efforts. Harvard Business School Working Paper, 2011

[6] Puig, S., M., Legal Goods Protected by the Law and Legal Cods Protected by the Criminal Law as Limits to the State's Power to Criminalize Conduct, in: New Criminal Law Review, vol. 11, no. 3, 2008, p. 410.

[7] Trevino, L., G. Weaver, D. Gibson and B. Toffler, Managing ethics and legal compliance. What works and what hurts, California Management Review, 41 131-1, 1999.

[8] Wood, D., Business and Society, Harper Collins Publishers, New York, 1990.

[9] Law no. 12/1990 republished in the Official Gazette of Romania, Part I, no. 133 of June 20, 1991 and amended and completed by the Government Ordinance no. 23/1992 on the amendment of some contravention sanctions, published in the Official Gazette of Romania, Part I, no. 213 of August 28, 1992, approved by Law no. 114/1992 regarding some Government ordinances issued under Law no. 81/1992 enables the Government ability to issue ordinances and authorizing contracting or guaranteeing the external loans, published in the Official Gazette of Romania, Part I, no. 311 of 30 November 1992; Government Ordinance no. 55/1994 regarding the increase of the minimum and maximum contravention fines set by the laws in force on 1 June 1994, published in the Official Gazette of Romania, Part I, no. 242 of August 29, 1994, approved by Law no. 129/1994, published in Official Gazette of Romania, Part I, no. 354 of 21 December 1994; Law no. 105/1997 to resolve the objections, appeals and complaints on the amounts established and applied by the acts of control or imposing of the bodies of the Ministry of Finance, published in the Official Gazette of Romania, Part I, no. 136 of 30 June 1997, repealed by the Government Emergency Ordinance no. 13/2001 regarding to solve the complaints against the measures taken by the acts imposing control or bodies established by the Ministry of Finance, repealed, in turn, by the Government Ordinance no. 92/2003 regarding the Fiscal Procedure Code, republished; Government Ordinance no. $126 / 1998$ on amending by Law no. $12 / 1990$ on the protection of the population against the illicit commercial activities, published in the Official Gazette of Romania, Part I, no. 328 of 29 August 1998, approved by Law no. 243/1998, published in Official Gazette of Romania, Part I, no. 488 of 18 December 1998; Law no. 177/1998 for 


\author{
(online) $=$ ISSN $2285-3642$ \\ ISSN-L = 2285 - 3642 \\ Journal of Economic Development, Environment and People \\ Volume 3, Issue 3, 2014 \\ URL: http://jedep.spiruharet.ro \\ e-mail: office jedep@spiruharet.ro
}

supplementing Article 2 of Law no. 12/1990 on the protection of the population against the illicit commercial activities, published in the Official Gazette of Romania, Part I, no. 388 of 13 October 1998; Law no. 210/2007 amending and supplementing of some normative acts which are established and are sanctioned the offences, published in the Official Gazette of Romania, Part I, no. 485 of 19 July 2007, republished in the Official Gazette no. 291 of 5 May 2009;

[10] In the Official Gazette of Romania no. 428 of 28 June 2012 was published Decision no. $498 / 2012$ regarding the exception of unconstitutionality of Article 1 letter g) of Law no. 12/1990 on the protection of the population against some illicit commercial activities on http://www.curierulfiscal.ro/2012/07/05/unele-dispozitii-din-legeanr-121990-privind-protejarea-populatiei-impotriva-unor-activitati-comerciale-ilicite-sunt-neconstitutionale/ accessed on 15.09.2012;

[11] Published in the Official Gazette of Romania no. 24 of 30.01.1991, as amended by Law no. 298/2001 amending and supplementing Law no. 11/1991 on combating the unfair competition, published in Official Gazette Part I no. 313 of 12.06.2001; Law no. 21/1996 (Competition Law), published in the Official Gazette no. 88 of 30/04/1996 and republished in the Official Gazette, Part I no. 742 of 16/08/2005 accessed on 16.09.2012

[12] Transparency International Romania, Ghid anticorupţie în justiţie pentru cetăţeni şi oameni de afaceri, 2006, p.4. 